\title{
Current Antiviral Therapy of Chronic Hepatitis B: Efficacy and Safety
}

\author{
Yuk-Fai Lam • Man-Fung Yuen • Wai-Kay Seto • \\ Ching-Lung Lai
}

Published online: 9 August 2011

(C) The Author(s) 2011. This article is published with open access at Springerlink.com

\begin{abstract}
The treatment of chronic hepatitis B is in constant evolution. Interferon, the first agent licensed for chronic hepatitis B treatment, has been superseded by the growing popularity of nucleoside/nucleotide analogues (NA). However, resistance to these agents is a major challenge. Newer NAs, such as entecavir and tenofovir dipivoxil fumarate, have very low resistance rates and favorable safety profiles. Long-term use of these agents can effectively suppress hepatitis B virus DNA, leading to decrease in incidence of hepatitic flares, as well as in the development of cirrhosis and hepatocellular carcinoma. The efficacy and safety of various antiviral agents is discussed in this review.
\end{abstract}

Keywords Hepatitis B - Nucleos(t)ide Analogs .

Resistance $\cdot \mathrm{HBV}$ DNA

\section{Introduction}

Chronic hepatitis B (CHB) infection is a major health burden worldwide, with around 400 million people affected [1]. Patients with CHB have a $15 \%$ to $40 \%$ chance of developing cirrhosis, hepatic decompensation and hepatocellular carcinoma in their lifetime [2,3]. The risk of having hepatocellular carcinoma is increased by more than 100-200 fold compared to healthy subjects [4]. Currently two classes of agents are available for treatment of chronic hepatitis B, namely immunomodulatory therapy (conven-

Y.-F. Lam $(\bowtie) \cdot$ M.-F. Yuen • W.-K. Seto • C.-L. Lai

Department of Medicine,

The University of Hong Kong Queen Mary Hospital,

Pokfulam Road,

Hong Kong, Hong Kong

e-mail: lamyukfai@hotmail.com tional interferon and pegylated interferon) and nucleoside/ nucleotide analogs (NA).

\section{Conventional Interferon and Pegylated Interferon}

The first agent approved for treatment of chronic hepatitis $B$ was conventional interferon- $\alpha$ [5]. Pegylated-interferon, which was licensed in 2005, has the advantage of ease of administration when compared to conventional interferon. They mainly work through immunomodulation.

These agents decrease viral loads and increase rates of hepatitis $\mathrm{B}$ e antigen ( $\mathrm{HBeAg}$ ) seroconversion to antibody against $\mathrm{HBeAg}$ (anti-HBe) [6]. They also have the advantage of use for a finite duration. However, the course of treatment has been extended from 16 weeks with the conventional interferon to 48 weeks with pegylated interferon.

Interferons are poorly tolerated because of their severe side effects. The side effects include influenza-like illness, anorexia, flares of autoimmune disease, thyroid dysfunction, myelosuppression, hepatitis flare, hepatic decompensation, and neuropsychiatric adverse events like depression, irritability, and even suicidal tendency. High relapse rate and costs are also drawbacks of immunomodulatory therapy [7, 8].

On long-term follow-up, a majority of patients still have detectable hepatitis B virus (HBV) DNA after interferon treatment $[9,10]$. In addition, most studies fail to demonstrate a reduction in incidence of hepatocellular carcinoma with conventional interferon on long term follow-up [11-13].

\section{Nucleoside/Nucleotide Analogue}

Currently five NAs are approved for the treatment of CHB. They are lamivudine, adefovir dipivoxil (ADV), 
telbivudine, entecavir and tenofovir disoproxil fumarate (TDF) (Tables 1 and 2)

They are effective in suppressing viral loads, facilitating HBeAg seroconversion, achieving alanine aminotransferase (ALT) normalization, and improving liver fibrosis.

They are generally well tolerated and serious adverse events are rarely encountered [14-17].

There is growing evidence that prolonged and effective suppression of HBV DNA can decrease the risk of cirrhosis and hepatocellular carcinoma. Therefore the current trend of treatment for chronic hepatitis B is to use long term NA therapy to achieve permanent virologic suppression, with loss of hepatitis B surface antigen (HBsAg) as the ideal end-point $[18 \bullet]$.

The comparative efficacy and resistance rates of the five nucleoside and nucleotide analogues are shown in Table 1 and 2 respectively.

\section{Lamivudine}

Lamivudine was originally used for HIV infection. It was approved by the United States Food and Drug Administration (FDA) in 1998 as the first nucleoside analogue for the treatment of CHB. Lamivudine is the (-) enantiomer of 2', $3^{\prime}$ - dideoxy $3^{\prime}$ thiacytidine. It is phosphorlyated into the triphosphate form (3TC-TP) and is incorporated into the growing chain of DNA during reverse transcription of the first strand of HBV DNA and synthesis of the second strand of HBV DNA, resulting in chain termination and inhibiting HBV DNA synthesis [15, 19].

\section{Efficacy and Resistance}

Lamivudine is effective in suppressing viral replication in both $\mathrm{HBeAg}$-positive and $\mathrm{HBeAg}$-negative patients.
The Asia Hepatitis Lamivudine Study Group concluded that lamivudine $100 \mathrm{mg}$, when compared to placebo, achieved a higher rate of $\mathrm{HBeAg}$ seroconversion $(16 \%$ versus $4 \%)$ and sustained ALT normalization (72\% versus $24 \%$ ) at 1 year. Greater proportion of patients in the group receiving lamivudine $100 \mathrm{mg}$ daily, when compared to placebo, achieved improvement of necroinflammatory activity by 2 points or more at 1 year $(56 \%$ versus $25 \%)$ [20]. The efficacy of lamivudine is confirmed by another multicentre trial performed in the United States. HBeAgpositive patients on lamivudine $100 \mathrm{mg}$ daily, as compared to placebo, have higher rates of histological improvement (52\% versus $23 \%), \mathrm{HBeAg}$ seroconversion $(32 \%$ versus $11 \%$ ), undetectable HBV DNA (44\% versus $16 \%$ ) and alanine aminotransferase normalization (41\% versus $16 \%)$ at 48 weeks [21]. For extended lamivudine therapy to 3 years, more patients achieved $\mathrm{HBeAg}$ seroconversion, alanine aminotransferase normalization and sustained HBV DNA suppression [22].

Lamivudine is also efficacious in HBeAg-negative patients. After 1 year of treatment, $96 \%$ of patients achieved alanine aminotransferase normalization and $68 \%$ achieved undetectable HBV DNA [23].

Lamivudine is effective in preventing progression of cirrhosis and developing of hepatocellular carcinoma [2426]. A large prospective study for patients with established cirrhosis [27] showed that patients on lamivudine $100 \mathrm{mg}$ daily, compared to placebo, were less likely to have increase in Child-Turcotte- Pugh (CTP) score (3.4\% versus $8.8 \%)$ and development of hepatocellular carcinoma $(3.9 \%$ versus $7.4 \%$ ). In fact, this study, originally planned for a follow-up period of 5 years, was terminated at median of 32.4 months because of the significant differences observed between the treatment group and the placebo group.

Table 1 Efficacy of nucleoside/nucleotide analogs treatment for chronic hepatitis B (HBeAg-positive/HBeAg-negative)

\begin{tabular}{|c|c|c|c|c|c|}
\hline & Lamivudine $[20,22,23,32]$ & ADV $[39-41,45]$ & Telbivudine $[48,52]$ & Entecavir [59-63] & $\operatorname{TDF}[71,72,74,75]$ \\
\hline \multicolumn{6}{|c|}{ Rate of $\mathrm{HBeAg}$ seroconversion (\%) } \\
\hline 1 year & $16 /-$ & $12 /-$ & $23 /-$ & $21 /-$ & $21 /-$ \\
\hline 2 year & $29 /-$ & $29 /-$ & $30 /-$ & $31 /-$ & $27 /-$ \\
\hline $4\left(\right.$ or $\left.5^{\mathrm{a}}\right)$ year & $47 /-$ & $48 /-^{\mathrm{a}}$ & $\mathrm{NA} /-$ & $44 /-^{a}$ & $29 /-$ \\
\hline \multicolumn{6}{|c|}{ ALT normalization (\%) } \\
\hline 1 year & $72 / 96$ & $48 / 72$ & $77 / 74$ & $68 / 78$ & $68 / 76$ \\
\hline 2 year & NA/60 & $74 / 73$ & $70 / 77$ & $87 / 89$ & $\mathrm{NA} / \mathrm{NA}$ \\
\hline $4\left(\right.$ or $\left.5^{\mathrm{a}}\right)$ year & 69/NA & $\mathrm{NA} / 69^{\mathrm{a}}$ & NA/NA & $80 / \mathrm{NA}^{\mathrm{a}}$ & $\mathrm{NA} / \mathrm{NA}$ \\
\hline \multicolumn{6}{|c|}{ Undetectable HBV DNA by PCR (\%) } \\
\hline 1 year & $36 / 68$ & $21 / 51$ & $60 / 88$ & $67 / 90$ & $76 / 93$ \\
\hline 2 year & NA/42 & $40 / 71$ & $56 / 82$ & $80 / 94$ & $89 / 91$ \\
\hline $4\left(\right.$ or $\left.5^{\mathrm{a}}\right)$ year & $\mathrm{NA} / \mathrm{NA}$ & $\mathrm{NA} / 67^{\mathrm{a}}$ & NA/NA & $94 / \mathrm{NA}^{\mathrm{a}}$ & $96 / 100$ \\
\hline
\end{tabular}

$A L T$ alanine aminotransferase, $H B e A g$ hepatitis B e-antigen, $N A$ not available

a denotes 5 year data 
Table 2 Resistance rate of nucleoside/nucleotide analogs for treatment of chronic hepatitis B

$N A$ not available

\begin{tabular}{|c|c|c|c|c|c|}
\hline & $\begin{array}{l}\text { Lamivudine } \\
{[20,22,32]}\end{array}$ & $\begin{array}{l}\text { ADV } \\
{[39-41,45]}\end{array}$ & $\begin{array}{l}\text { Telbivudine } \\
{[48,52]}\end{array}$ & $\begin{array}{l}\text { Entecavir } \\
\text { [59-63] }\end{array}$ & $\begin{array}{l}\text { TDF } \\
{[71,72,74,75]}\end{array}$ \\
\hline \multicolumn{6}{|c|}{ Resistance (\%) } \\
\hline 1 year & 14 & 0 & $2.2-5$ & 0 & 0 \\
\hline 2 year & 39 & 3 & $10.8-25.1$ & $<1$ & 0 \\
\hline 5 year & $60-70$ & $20-29$ & NA & 1.2 & NA \\
\hline
\end{tabular}

The major problem with long-term lamivudine therapy is drug resistance. Lamivudine is known to have a low genetic barrier. The classical mutation associated with lamivudine is $\mathrm{rtM} 204 \mathrm{~V} / \mathrm{I}$ and $\mathrm{rtL} 180 \mathrm{M}$ located in the YMDD locus of hepatitis B virus polymerase [20, 21, 28, 29].

The rate of undetectable HBV DNA decreased from $77 \%$ at 12 months of lamivudine treatment, to $52 \%$ at 24 months and $42 \%$ at 36 months, mainly due to development of drug resistance [23, 30]. For cirrhotic patients on lamivudine, those who have drug resistance are more likely to have increase CTP score when compared to patients without lamivudine resistance [27]. Hepatitic flares and even liver failure were described in patients with lamivudine resistance. Hepatitic flare was noted in $10 \%$ of lamivudine- treated patients at 1 year and $18 \%$ at 2 years $[30,31]$.

\section{Safety}

Lamivudine has excellent safety profile. Long term study up to 6 years showed no major adverse events and complications associated with lamivudine treatment $[30,32]$.

\section{Current Roles of Lamivudine Therapy}

In view of the low genetic barrier of lamivudine, it is not recommended as the first line treatment for CHB [33•, 34•]. However, lamivudine may have a role as monotherapy for those with these favorable parameters: Baseline HBV DNA less than $9 \log$, ALT higher than or equal to 2 times upper limit of normal and good viral suppression of less than 4 $\log$ at week 4 . The rate of lamivudine resistance for patients who have these favorable parameters is low [35].

Lamivudine also has a role as preemptive treatment for CHB patients receiving a finite course of immunosuppression or chemotherapy [36, 37]. The American Association for the Study of Liver Disease guidelines recommends that lamivudine can be used as prophylactic treatment if the anticipated duration of immunosuppression or chemotherapy is less than 12 months and the baseline HBV DNA is undetectable [33•].

Although lamivudine is classified as a pregnancy Category $\mathrm{C}$ drug, lamivudine has long term safety data in pregnancy. Pregnant women on lamivudine have the same rate of birth defect compared to the general population [38].
Lamivudine is also useful for patients who have resistance toward adefovir dipivoxil as they have different pattern in viral resistance [33•]. However, entecavir is superior to lamivudine for patients with adevfovir resistance.

\section{Adefovir Dipivoxil}

ADV was approved by the United States FDA for treatment of chronic hepatitis B in 2002. ADV is a nucleotide analog. It is converted into adefovir and phosphorylated into its active form in the body. Adefovir diphosphonate is incorporated into the viral DNA and thus inhibits HBV DNA reverse transcription and viral replication [14].

\section{Efficacy and Resistance}

In a phase III trial involving 515 HBeAg-positive patients who were treated with ADV or placebo, more patients in the adefovir group achieved undetectable HBV DNA (21\% versus 0\%), alanine aminotransferase normalization ( $48 \%$ versus $16 \%$ ), histological improvement (53\% versus 25\%) and HBeAg seoconversion (12\% versus $6 \%$ ) at 48 weeks of treatment [39]. A second study confirmed the efficacy of ADV in HBeAg-negative patients. Patients receiving ADV $10 \mathrm{mg}$ daily when compared with placebo, achieved greater response in terms of histologic improvement (64\% versus 33\%), undetectable HBV DNA (51\% versus $0 \%$ ) and normalization of alanine aminotransferase (72\% versus 29\%) at 48 weeks [40]. Further clinical studies show that extended ADV monotherapy up to 5 years can achieve better histological, virologic and biochemical outcomes [41].

For patients who have lamivudine resistance, combination therapy of lamivudine and adefovir or adefovir monotherapy can achieve alanine aminotransferse normalization and HBV DNA suppression [42]. However recent studies favor the approach of adding adefovir to lamivudine in lamivudine resistant patients instead of switching to adefovir monotherapy because the latter approach may lead to a higher risk of adefovir resistance (7\% versus $18 \%$ at 2 years) [43].

$\mathrm{ADV}$ is efficacious in decompensated cirrhosis. In a study involving 226 lamivudine-resistant patients with 
decompensated cirrhosis awaiting liver transplant, HBV DNA became undetectable in $59 \%$ and $65 \%$ at week 48 and 96 with ADV treatment [44]. In the same study with 241 post-liver transplantation lamivudine-resistant $\mathrm{CHB}$ patients, HBV DNA became undetectable in $40 \%$ and $65 \%$ at weeks 48 and 96 with ADV treatment. There is also improvement of CTP score with adefovir treatment in lamivudine-resistant chronic hepatitis B cirrhosis.

Cumulative rate of genotypic resistance to ADV at 5 years for $\mathrm{HBeAg}$-positive and HBeAg-negative patients are $20 \%$ and $29 \%$, respectively [41, 45]. The mutations associated with adefovir are N236T and A181V/T [46]. Viruses with these 2 mutations remain susceptible to entecavir whereas viruses with $\mathrm{A} 181 \mathrm{~V} / \mathrm{T}$ mutations are cross-resistant to lamivudine [47].

\section{Safety}

The major side effect of ADV is nephrotoxicity. Studies using ADV $10 \mathrm{mg}$ versus ADV $30 \mathrm{mg}$ found that the higher dose is associated with greater impairment of renal function [39]. ADV at $10 \mathrm{mg}$ is well tolerated and renal side effects are reported in $3 \%$ of patients with compensated liver disease after 5 years of treatment [41]. The renal impairment is reversible with dose reduction or drug withdrawal. For patients receiving ADV, renal function should be monitored every 3 months or more frequently if there is pre-existing renal impairment [33•].

\section{Current Role of Adefovir Therapy}

With the availability of newer agents, such as entecavir and TDF with high antiviral efficacy and high genetic barrier, ADV monotherapy is no longer recommended as the first option for treatment-naïve patients [33•, 34].

In the case of lamivudine or telbivudine resistance, adefovir therapy is shown to be useful. It is recommended that ADV is added to lamivudine/telbivudine instead of switching to ADV monotherapy [43]. However, TDF is superior to ADV for these patients. In the case of renal impairment, ADV is best avoided. If it is used, dosage should be adjusted and close monitoring of renal function is necessary.

\section{Telbivudine}

Telbivudine was approved by the United States FDA for treatment of CHB in 2006. Telbivudine is the L-enantiomer of thymidine. After phosphorylation into active triphosphate form, it is incorporated into HBV viral DNA and causes termination of chain synthesis, thereby suppressing HBV DNA replication.
Efficacy and Resistance

In the GLOBE trial [48], 1367 patients including both HBeAg-positive and HBeAg-negative patients were randomized to telbivudine $600 \mathrm{mg}$ daily and lamivudine $100 \mathrm{mg}$ daily for 1 year. In HBeAg-positive patients, patients on telbivudine, when compared to lamivudine, are more likely to achieve undetectable HBV DNA $(<300$ copies $/ \mathrm{mL})(60 \%$ versus $40.4 \%)$ and $\mathrm{HBeAg}$ seroconversion $(22.5 \%$ versus $21.5 \%)$. For HBeAg-negative patients, there was also a higher rate of undetectable HBV DNA for patients on telbivudine compared with lamivudine ( $88.3 \%$ versus $77.4 \%)$. Less patients on telbivudine developed drug resistance when compared to lamivudine in both HBeAg-positive (5.0\% versus $11.0 \%)$ and HBeAg-negative patients (2.2\% versus $10.7 \%)$. HBeAgpositive patients on telbivudine had better histologic response than those on lamivudine at 1 year $(64.7 \%$ versus 56.3\%). Another similar study performed in China also demonstrated superiority of telbivudine to lamivudine in terms of undetectable HBV DNA [49]. For chronic hepatitis B patients with cirrhosis, telbivudine can improve CTP score at 48 weeks of treatment $[49,50]$.

One of the major drawbacks with long-term telbivudine treatment is the development of drug resistance. The main mutation is rtM204I in the YMDD motif. Secondary mutations rtL80I/V and L80I/V + L180M may be associated with the rtM208I mutation. Unlike lamivudine, rtM204V is not associated with telbivudine resistance $[48,51]$.

After 2 years of therapy, the resistance is found in $25.1 \%$ of $\mathrm{HBeAg}$-positive and $10.8 \%$ of HBeAg-negative patients [52].

\section{Safety}

One of the major concerns with telbivudine use is elevation of creatine kinase (CK) and myopathy. According to the Novartis global database for patients treated over 4 years, $14 \%$ to $17 \%$ of patients have grade $3 / 4 \mathrm{CK}$ elevation, most of which are transient [52]. A total of $1.1 \%$ of patients have myopathy and myositis, presenting with muscle weakness and pain. There is poor correlation between CK elevation and myopathy/myositis as only $30 \%$ of these patients have concomitant grade 3/4 CK elevations [53].

In addition, there is also the development of peripheral neuropathy with the use of telbivudine, especially when used together with pegylated interferon [54]. The clinical trial of telbivudine and pegylated interferon was terminated because of the high incidence (18\%) of peripheral neuropathy.

Telbivudine is a pregnancy category B drug. In a study involving 61 pregnant women in China to determine the efficacy of telbivudine in decreasing maternal transmission of the hepatitis B virus to their infants, no adverse effects 
were observed in both the mothers and the newborns in telbivudine-treated patients [55].

Current Role of Telbivudine Therapy

Both the American Association for the Study of Liver Disease and European Association for the Study of the Liver guidelines do not recommend telbivudine as the first line of treatment due to the high rate of drug resistance with long-term use $[33 \bullet, 34 \bullet]$. In multivariate analyses of the GLOBE study data, low baseline HBV DNA $(<9 \log 10$ for $\mathrm{HBeAg}$ positive patients, $<7 \log 10$ for $\mathrm{HBe}$-negative patients) and undetectable HBV DNA at 24 weeks $(<300$ copies per $\mathrm{mL}$ ) are associated with low rate of resistance at 2 years (HBeAg positive: $1.8 \%$; $\mathrm{HBeAg}$ negative: $2.3 \%$ ) [56]. A recent study showed that HBV DNA level of less than $200 \mathrm{IU} / \mathrm{mL}$ at week 12 of telbivudine therapy was also predictive of higher chance of undetectable HBV DNA (78.6\%) and lower chance of resistance (0\%) at year 3 [57]. Telbivudine may have a role in patients with these favorable characteristics.

\section{Entecavir}

Entecavir was approved by the FDA as the third nucleoside analog for the treatment of chronic hepatitis B in 2005. Entecavir is a guanosine analogue. It undergoes phosphorylation into di-phosphate and tri-phosphate metabolites, which is then incorporated into HBV DNA polymerase to inhibit viral replication. It also inhibits the priming of HBV DNA polymerase, a step which involves guanosine [58]. The inhibition of the priming of HBV DNA polymerase is unique among the currently licensed nucleoside/nucleotides.

\section{Efficacy and Resistance}

Entecavir has significant antiviral activity against chronic hepatitis B. In a double blinded prospective study, 715 $\mathrm{HBeAg}$-positive patients were randomized to receive the standard doses of entecavir or lamivudine. More patients in the entecavir group achieve undetectable HBV DNA levels (67\% versus $36 \%$ ), alanine aminotransferase normalization $(68 \%$ versus $60 \%)$ and histological improvement $(72 \%$ versus $62 \%$ ) at 48 weeks of treatment. The reduction of HBV DNA from baseline to week 48 was greater with entecavir than with lamivudine (6.9 versus $5.4 \mathrm{log}$ copies per $\mathrm{mL}$ ). $\mathrm{HBeAg}$ seroconversion rate at 48 weeks with entecavir group was $21 \%$, while that for lamivudine group was $18 \%$ [59]. Entecavir is also effective for $\mathrm{HBeAg}$ negative patients. In a parallel prospective study involving $648 \mathrm{HBeAg-negative} \mathrm{CHB} \mathrm{patients,} \mathrm{who} \mathrm{were} \mathrm{randomized}$ to the standard doses of entecavir or lamivudine for
52 weeks, more patients in the entecavir group achieved undetectable HBV DNA ( $90 \%$ versus $72 \%$ ), normalization of ALT (78\% versus $71 \%)$ and histological improvement $(70 \%$ versus $61 \%$ ). The mean reduction of HBV DNA was higher in entecavir group (5.0 versus $4.5 \log$ copies per $\mathrm{mL}$ ) [60].

While the efficacy of earlier generation nucleoside/ nucleotide analogs decreases with time due to development of resistance, entecavir demonstrates potent antiviral efficacy for up to 5 years [61-63]. For patients taking entecavir up to 5 years, 94\% achieved undetectable HBV DNA and $80 \%$ had normal ALT levels. After 96 weeks of treatment, 31\% had HBeAg seroconversion; $5.1 \%$ also had HBsAg seroconversion. After 5 years, an additional $23 \%$ had $\mathrm{HBeAg}$ seroconversion; and $1.4 \%$ had HBsAg seroconversion [63].

Long term monitoring showed entecavir has a low resistance rate in treatment-naïve patients up to 5 years. The cumulative probability of genotypic entecavir resistance was $1.2 \%[64 \bullet]$. Entecavir resistance only occurs when, in addition to the two substitutions associated with lamivudine resistance (M204I/V +/- L180M), a third "signature" substitution develops at positions T184, S202 or M250 [65]. Therefore, for patients who have lamivudine resistance, there is lower genetic barrier for development of entecavir resistance. For this group of patients, the cumulative probability of genotypic entecavir resistance and genotypic resistance associated with virological breakthrough was $51 \%$ and $43 \%$, respectively at 5 years. Because of this, entecavir is not recommended in patients with lamivudine resistance [64•].

\section{Safety}

Entecavir has similar safety profile with lamivudine. Serious adverse events are rarely seen [59, 60]. In a preclinical animal study, there is a higher incidence of species-specific solid tumors with doses of entecavir above the therapeutic range compared to placebo [66]. However, post-market surveillance up to 2009 failed to show any increase in incidence of malignancy with entecavir use [67]. Five cases of lactic acidosis on entecavir for decompensated HBV cirrhosis were reported [68]. However, the lactic acidosis was reversible in 4 of the patients. It is not certain whether the lactic acidosis was related to the multiorgan failure of the patients or to entecavir.

\section{Current Role of Entecavir Therapy}

Sustained effective virologic suppression is essential in prevention of complications of chronic hepatitis B. Entecavir has high antiviral potency, low resistance rate, and excellent safety profile with prolonged use. Entecavir is therefore one of the "ideal" treatment options for $\mathrm{CHB}$, especially for treatment-naïve individuals. Both the 
AASLD and EASL guidelines recommend entecavir as one of the first line agents for treatment of chronic hepatitis B $[33 \cdot, 34 \bullet]$.

\section{Tenofovir Disoproxil Fumarate}

TDF is a nucleotide analogue initially approved for the treatment of HIV infection. It was approved by the United States FDA in 2008 for treatment of CHB. TDF is a prodrug of tenofovir. Tenofovir is phosphorylated into its active form and binds directly with viral polymerase and thereby suppressing viral replication $[69,70]$.

\section{Efficacy and Resistance}

Tenofovir and adefovir share similar molecular structure; tenofovir is found to be as potent as adefovir in an equal molar basis in in-vitro study. As tenofovir is less nephrotoxic, the approved daily dose of tenofovir is $300 \mathrm{mg}$ which is more potent than adefovir at $10 \mathrm{mg}$.In a pivotal trial comparing tenofovir and adefovir, more patients achieved undetectable HBV DNA (HBV DNA $<400$ copies per $\mathrm{mL}$ ) at 48 weeks in tenofovir group in both $\mathrm{HBeAg}$-positive (76\% versus $13 \%)$ and $\mathrm{HBeAg-negative} \mathrm{(93 \%} \mathrm{versus} 63 \%)$ patients [71]. All patients were put on open-label tenofovir after 48 weeks. At week 144 of tenofovir treatment, $93 \%$ of HBeAg-positive and $99 \%$ of HBeAg-negative patients have undetectable HBV DNA [72]. Furthermore, no resistance to tenofovir was detected up to week $192[73 \cdot, 74,75]$.

Several studies have demonstrated antiviral efficacy of tenofovir in lamivudine resistant patients. An Australian prospective study involving 60 patients with incomplete virologic response to both lamivudine and adefovir were given TDF or combination of TDF and lamivudine, $64 \%$ of patients achieved undetectable HBV DNA $(<15 \mathrm{IU} / \mathrm{mL})[76]$.

HBV mutation associated with adefovir resistant $\mathrm{rtN} 236 \mathrm{~T}$ and $\mathrm{rtA} 181 \mathrm{~V} / \mathrm{T}$ are associated with decrease in response to tenofovir in in-vitro studies [77, 78]. However, clinical studies on tenofovir showed mixed results in adefovir resistant patients $[76,79,80]$. A retrospective multicenter study involving patients with treatment failure with lamivudine, adefovir, entecavir, either as sequential or add-on therapy, showed that TDF was less efficacious in patients with adefovir-associated mutations compared to lamviduine-associated mutations (52\% versus $100 \%)$ in achieving undetectable HBV DNA $(<400$ copies per $\mathrm{mL}$ ) [79]. However, no patients had virological breakthrough in the observed period of the study. In another German study involving 105 adefovir treated patients, $81 \%$ of patients have undetectable HBV DNA ( $<400$ copies per ml) at week 48. The treatment response was not affected by baseline ADV- resistance or lamivudine resistance [80].
In decompensated liver disease, TDF has comparable improvement of virological, biochemical and clinical parameters compared to entecavir. Both agents achieved similar rates of HBV DNA undetectability (HBV DNA $<400$ copies per $\mathrm{mL}$ ) at week 48 , normal alanine aminotransferase and improvement of CTP score [81].

There is no report of virologic resistance of TDF in chronic hepatitis B monoinfection [73•]. In a study involving patients with HBV-HIV coinfection, rtA194T is found to be associated with reduced susceptibility to TDF in-vitro when lamivudine mutations rtM204V and rtL180m were present [82]. However, this is not confirmed by another study [83]. The role of rtA194T in TDF resistance is still unknown.

Safety

From the experience in HIV infection, tenofovir is associated with a small decline in renal function of $9.8 \mathrm{~mL} / \mathrm{min} / 1.37 \mathrm{~m} 2$ in 5 years [84]. However, large scale clinical studies showed there is no evidence of compromised renal function with tenofovir in patients with chronic hepatitis B monoinfection [72]. TDF is also associated with renal proximal tubular disfunction and renal phosphate wasting [85]. Cases of acute renal failure and nephrogenic diabetes insipidus have been reported [86]. Renal toxicity is usually reversible when tenofovir is stopped.

TDF is a pregnancy category B drug. There is no increase in rate of birth defects in HIV infected mother taking tenofovir compared to baseline [34].

\section{Current Role of TDF Therapy}

TDF is recommended as the one of the first line agents for treatment naïve patients. Given the potent antiviral efficacy, low resistance rate and minimal toxicity, it can achieve long term effective HBV DNA suppression and has the potential to become one of the "ideal" treatment options for chronic hepatitis B. Tenofovir is also useful in patients with lamivudine, telbivudine and entecavir resistance.

\section{Conclusions}

Over the past 10 years, there has been considerable improvement in the treatment of chronic hepatitis B. Interferon-based immunomodulatory therapy is gradually being replaced by nucleoside/nucleotide analogs which have better antiviral potency and safety profiles.

Newer nucleoside/nucleotide analogs including entecavir and TDF have potent antiviral potency and high genetic barrier to resistance, and thus are superior to agents such as lamivudine, telbivudine, and adefovir. 
Current treatment strategy of chronic hepatitis B is to achieve prolonged and effective viral suppression [18•]. Due to the presence of intracellular covalently closed circular DNA in hepatocytes, there is a chance of viral rebound if NA is discontinued even when the serum HBV DNA have declined to levels below the detectable limits of polymerase chain reaction assays.

With the availability of entecavir and more recently TDF, prolonged effective viral suppression can be achieved with long-term treatment. It is likely that the complications with CHB including cirrhosis and hepatocellular carcinoma will decrease in the future with these newer agents.

However, more studies on the safety profiles and efficacy on long term use of these newer agents are needed.

Disclosure Ching-Lung Lai acted as speaker for GlaxoSmithKline, Bristol Myers-Squibb and Gilead; Man-Fung Yuen acted as consultant/ speaker and received research grants from Bristol Myers-Squibb, GlaxoSmithKline, Novartis and Roche Diagnostics; Yuk-Fai Lam and Wai-Kay Seto reported no potential conflicts of interest relevant to this article.

Open Access This article is distributed under the terms of the Creative Commons Attribution Noncommercial License which permits any noncommercial use, distribution, and reproduction in any medium, provided the original author(s) and source are credited.

\section{References}

Papers of particular interest, published recently, have been highlighted as:

- Of importance

1. Lai CL, Yuen MF. The natural history and treatment of chronic hepatitis B: a critical evaluation of standard treatment criteria and end points. Ann Intern Med. 2007;147:58-61.

2. Beasley RP. Hepatitis B virus. The major etiology of hepatocellular carcinoma. Cancer. 1988;61:1942-56.

3. Bosch FX, Ribes J, Cleries R, et al. Epidemiology of hepatocellular carcinoma. Clin Liver Dis. 2005;9:191-211. v.

4. Beasley RP, Hwang LY, Lin CC, et al. Hepatocellular carcinoma and hepatitis B virus. A prospective study of $22707 \mathrm{men}$ in Taiwan. Lancet. 1981;2:1129-33.

5. Hoofnagle JH, di Bisceglie AM. The treatment of chronic viral hepatitis. N Engl J Med. 1997;336:347-56.

6. Wong DK, Cheung AM, O'Rourke K, et al. Effect of alphainterferon treatment in patients with hepatitis $\mathrm{B}$ e antigen-positive chronic hepatitis B. A meta-analysis. Ann Intern Med. 1993;119:312-23.

7. Brunetto MR, Oliveri F, Rocca G, et al. Natural course and response to interferon of chronic hepatitis $\mathrm{B}$ accompanied by antibody to hepatitis B e antigen. Hepatology. 1989;10:198-202.

8. Brunetto MR, Giarin M, Saracco G, et al. Hepatitis B virus unable to secrete e antigen and response to interferon in chronic hepatitis B. Gastroenterology. 1993;105:845-50.
9. Wong VW, Wong GL, Yan KK, et al. Durability of peginterferon alfa- $2 \mathrm{~b}$ treatment at 5 years in patients with hepatitis B e antigen-positive chronic hepatitis B. Hepatology. 2010;51:1945-53.

10. Marcellin P, Bonino F, Lau GK, et al. Sustained response of hepatitis $\mathrm{B}$ e antigen-negative patients 3 years after treatment with peginterferon alpha-2a. Gastroenterology. 2009;136:216979. e1-4.

11. Yuen MF, Hui CK, Cheng CC, et al. Long-term follow-up of interferon alfa treatment in Chinese patients with chronic hepatitis B infection: the effect on hepatitis B e antigen seroconversion and the development of cirrhosis-related complications. Hepatology. 2001;34:139-45.

12. Truong BX, Seo Y, Kato M, et al. Long-term follow-up of Japanese patients with chronic hepatitis B treated with interferonalpha. Int J Mol Med. 2005;16:279-84.

13. Lin SM, Yu ML, Lee CM, et al. Interferon therapy in $\mathrm{HBeAg}$ positive chronic hepatitis reduces progression to cirrhosis and hepatocellular carcinoma. J Hepatol. 2007;46:45-52.

14. Dando T, Plosker G. Adefovir dipivoxil: a review of its use in chronic hepatitis B. Drugs. 2003;63:2215-34.

15. Lai CL, Yuen MF. Profound suppression of hepatitis B virus replication with lamivudine. J Med Virol. 2000;61:367-73.

16. Rivkin A. A review of entecavir in the treatment of chronic hepatitis B infection. Curr Med Res Opin. 2005;21:1845-56.

17. But DY, Yuen MF, Fung J, et al. Safety evaluation of telbivudine. Expert Opin Drug Saf. 2010;9:821-9.

18. - Lai CL, Yuen MF. Chronic hepatitis B-new goals, new treatment. N Engl J Med. 2008;359:2488-91. This article suggests the new goal of chronic hepatitis B treatment should be prolonged and effective viral suppression. The authors also provide evidence to support this.

19. Severini A, Liu XY, Wilson JS, et al. Mechanism of inhibition of duck hepatitis $B$ virus polymerase by (-)-beta-L-2', $3^{\prime}$ dideoxy-3'-thiacytidine. Antimicrob Agents Chemother. 1995;39:1430-5.

20. Lai CL, Chien RN, Leung NW, et al. A one-year trial of lamivudine for chronic hepatitis B. Asia Hepatitis Lamivudine Study Group. N Engl J Med. 1998;339:61-8.

21. Dienstag JL, Schiff ER, Wright TL, et al. Lamivudine as initial treatment for chronic hepatitis B in the United States. N Engl J Med. 1999;341:1256-63.

22. Leung NW, Lai CL, Chang TT, et al. Extended lamivudine treatment in patients with chronic hepatitis B enhances hepatitis B e antigen seroconversion rates: results after 3 years of therapy. Hepatology. 2001;33:1527-32.

23. Hadziyannis SJ, Papatheodoridis GV, Dimou E, et al. Efficacy of long-term lamivudine monotherapy in patients with hepatitis B e antigen-negative chronic hepatitis B. Hepatology. 2000;32:84751.

24. Di Marco V, Marzano A, Lampertico P, et al. Clinical outcome of HBeAg-negative chronic hepatitis $B$ in relation to virological response to lamivudine. Hepatology. 2004;40:883-91.

25. Villeneuve JP, Condreay LD, Willems B, et al. Lamivudine treatment for decompensated cirrhosis resulting from chronic hepatitis B. Hepatology. 2000;31:207-10.

26. Yuen MF, Seto WK, Chow DH, et al. Long-term lamivudine therapy reduces the risk of long-term complications of chronic hepatitis B infection even in patients without advanced disease. Antivir Ther. 2007;12:1295-303.

27. Liaw YF, Sung JJ, Chow WC, et al. Lamivudine for patients with chronic hepatitis B and advanced liver disease. N Engl J Med. 2004;351:1521-31.

28. Stuyver LJ, Locarnini SA, Lok A, et al. Nomenclature for antiviral-resistant human hepatitis B virus mutations in the polymerase region. Hepatology. 2001;33:751-7. 
29. Yuen MF, Sablon E, Hui CK, et al. Factors associated with hepatitis B virus DNA breakthrough in patients receiving prolonged lamivudine therapy. Hepatology. 2001;34:785-91.

30. Lok AS, Lai CL, Leung N, et al. Long-term safety of lamivudine treatment in patients with chronic hepatitis B. Gastroenterology. 2003;125:1714-22.

31. Liaw YF, Chien RN, Yeh CT, et al. Acute exacerbation and hepatitis B virus clearance after emergence of YMDD motif mutation during lamivudine therapy. Hepatology. 1999;30:567-72.

32. Chang TT, Lai CL, Chien RN, et al. Four years of lamivudine treatment in Chinese patients with chronic hepatitis B. J Gastroenterol Hepatol. 2004;19:1276-82.

33. - Lok AS, McMahon BJ. Chronic hepatitis B: update 2009. Hepatology. 2009;50:661-2. This is the American Association for the Study of Liver Diseases Guideline, which gives a comprehensive overview on the management of chronic hepatitis $B$.

34. - EASL Clinical Practice Guidelines: management of chronic hepatitis. B. J Hepatol. 2009;50:227-42. This is the latest European Association for the Study of the Liver Guideline on the management of chronic hepatitis $B$.

35. Yuen MF, Fong DY, Wong DK, et al. Hepatitis B virus DNA levels at week 4 of lamivudine treatment predict the 5-year ideal response. Hepatology. 2007;46:1695-703.

36. Hsu C, Hsiung CA, Su IJ, et al. A revisit of prophylactic lamivudine for chemotherapy-associated hepatitis $\mathrm{B}$ reactivation in non-Hodgkin's lymphoma: a randomized trial. Hepatology. 2008;47:844-53.

37. Loomba R, Rowley A, Wesley R, et al. Systematic review: the effect of preventive lamivudine on hepatitis $\mathrm{B}$ reactivation during chemotherapy. Ann Intern Med. 2008;148:519-28.

38. Antiretroviral Pregnancy Registry Steering Committee. Antiretroviral pregnancy registry international interim report for 1 January 1989 through 31 January 2010. Available at http://www.apregistry. com/forms/interim_report.pdf. Accessed April 2011.

39. Marcellin P, Chang TT, Lim SG, et al. Adefovir dipivoxil for the treatment of hepatitis B e antigen-positive chronic hepatitis B. N Engl J Med. 2003;348:808-16.

40. Hadziyannis SJ, Tassopoulos NC, Heathcote EJ, et al. Adefovir dipivoxil for the treatment of hepatitis $\mathrm{B}$ e antigen-negative chronic hepatitis B. N Engl J Med. 2003;348:800-7.

41. Hadziyannis SJ, Tassopoulos NC, Heathcote EJ, et al. Long-term therapy with adefovir dipivoxil for $\mathrm{HBeAg}$-negative chronic hepatitis B for up to 5 years. Gastroenterology. 2006;131:174351.

42. Peters MG, Hann Hw H, Martin P, et al. Adefovir dipivoxil alone or in combination with lamivudine in patients with lamivudineresistant chronic hepatitis B. Gastroenterology. 2004;126:91-101.

43. Fung J, Lai CL, Yuen JC, et al. Adefovir dipivoxil monotherapy and combination therapy with lamivudine for the treatment of chronic hepatitis B in an Asian population. Antivir Ther. 2007;12:41-6.

44. Schiff E, Lai CL, Hadziyannis S, et al. Adefovir dipivoxil for wait-listed and post-liver transplantation patients with lamivudineresistant hepatitis B: final long-term results. Liver Transpl. 2007;13:349-60.

45. Marcellin P, Chang TT, Lim SG, et al. Long-term efficacy and safety of adefovir dipivoxil for the treatment of hepatitis $B$ e antigen-positive chronic hepatitis B. Hepatology. 2008;48:750-8.

46. Angus P, Vaughan R, Xiong S, et al. Resistance to adefovir dipivoxil therapy associated with the selection of a novel mutation in the HBV polymerase. Gastroenterology. 2003;125:292-7.

47. Libbrecht E, Doutreloigne J, Van De Velde H, et al. Evolution of primary and compensatory lamivudine resistance mutations in chronic hepatitis B virus-infected patients during long-term lamivudine treatment, assessed by a line probe assay. J Clin Microbiol. 2007;45:3935-41.
48. Lai CL, Gane E, Liaw YF, et al. Telbivudine versus lamivudine in patients with chronic hepatitis B. N Engl J Med. 2007;357:257688.

49. Hou J, Yin YK, Xu D, et al. Telbivudine versus lamivudine in Chinese patients with chronic hepatitis B: Results at 1 year of a randomized, double-blind trial. Hepatology. 2008;47:447-54.

50. Liang J, Han T, Xiao SX, et al. Telbivudine treatment on cirrhosis resulting from chronic hepatitis B. Chin J Hepatol. 2009;17:24-7.

51. Zoulim F, Locarnini S. Hepatitis B virus resistance to nucleos $(\mathrm{t})$ ide analogues. Gastroenterology. 2009;137:1593-608. e1-2.

52. Liaw YF, Gane E, Leung N, et al. 2-Year GLOBE trial results: telbivudine Is superior to lamivudine in patients with chronic hepatitis B. Gastroenterology. 2009;136:486-95.

53. Avila, Goncalves. Creatine kinase elevations during 4 years of continuous telbivudine treatment are transient and not predictive of uncommonly observed muscle related symptoms. [abstract] 60th Annual Meeting of the American Association for the Study of the Liver Diseases (AASLD); Oct 30-Nov 3 2009; Boston, USA

54. Marcellin P, Avila C, Wursthorn K, et al. Telbivudine (LDT) plus Peg-interferon (PEGIFN) in HbeAg-positive chronic hepatitis Bvery potent antiviral efficacy but risk of peripheral neuropathy (PN) [abstract]. J Hepatol. 2010;52(S1):S6-7.

55. Zhang LJ, Wang L. Blocking intrauterine infection by telbivudine in pregnant chronic hepatitis B patients. Chin J Hepatol. 2009;17:561-3.

56. Zeuzem S, Gane E, Liaw YF, et al. Baseline characteristics and early on-treatment response predict the outcomes of 2 years of telbivudine treatment of chronic hepatitis B. J Hepatol. 2009;51:11-20.

57. Seto WK, Lai CL, Fung J et al. Significance of HBV DNA levels at 12 weeks of telbivudine treatment and the 3 years treatment outcome. J Hepatol 2010.

58. Seifer M, Hamatake RK, Colonno RJ, et al. In vitro inhibition of hepadnavirus polymerases by the triphosphates of BMS200475 and lobucavir. Antimicrob Agents Chemother. 1998;42:3200 8.

59. Chang TT, Gish RG, de Man R, et al. A comparison of entecavir and lamivudine for $\mathrm{HBeAg}$-positive chronic hepatitis B. N Engl J Med. 2006;354:1001-10.

60. Lai CL, Shouval D, Lok AS, et al. Entecavir versus lamivudine for patients with $\mathrm{HBeAg}$-negative chronic hepatitis B. N Engl J Med. 2006;354:1011-20.

61. Gish RG, Lok AS, Chang TT, et al. Entecavir therapy for up to 96 weeks in patients with HBeAg-positive chronic hepatitis B. Gastroenterology. 2007;133:1437-44.

62. Shouval D, Akarca US, Hatzis G, et al. Continued virologic and biochemical improvement through 96 weeks of entecavir treatment in $\mathrm{HBeAg}(-)$ Chronic Hepatitis B Patients (Study ETV-027). J Hepatol. 2006;44n Suppl 2:S21-22.

63. Chang TT, Lai CL, Kew Yoon S, et al. Entecavir treatment for up to 5 years in patients with hepatitis $\mathrm{B}$ e antigen-positive chronic hepatitis B. Hepatology. 2010;51:422-30.

64. - Tenney DJ, Rose RE, Baldick CJ, et al. Long-term monitoring shows hepatitis B virus resistance to entecavir in nucleoside-naive patients is rare through 5 years of therapy. Hepatology. 2009;49:1503-14. This article describes a very low rate of viral resistance with long term use of entecavir for treatment of chronic hepatitis $B$.

65. Tenney DJ, Levine SM, Rose RE, et al. Clinical emergence of entecavir-resistant hepatitis B virus requires additional substitutions in virus already resistant to Lamivudine. Antimicrob Agents Chemother. 2004;48:3498-507.

66. Entecavir Package Insert. Available at http://www.fda.gov. Accessed 1 April 2011

67. Fontana RJ. Side effects of long-term oral antiviral therapy for hepatitis B. Hepatology. 2009;49:S185-95. 
68. Lange CM, Bojunga J, Hofmann WP, et al. Severe lactic acidosis during treatment of chronic hepatitis B with entecavir in patients with impaired liver function. Hepatology. 2009;50:2001-6.

69. De Clercq E, Holy A. Acyclic nucleoside phosphonates: a key class of antiviral drugs. Nat Rev Drug Discov. 2005;4:928-40.

70. Ying C, De Clercq E, Nicholson W, et al. Inhibition of the replication of the DNA polymerase M550V mutation variant of human hepatitis B virus by adefovir, tenofovir, L-FMAU, DAPD, penciclovir and lobucavir. J Viral Hepat. 2000;7:161-5.

71. Marcellin P, Heathcote EJ, Buti M, et al. Tenofovir disoproxil fumarate versus adefovir dipivoxil for chronic hepatitis B. N Engl J Med. 2008;359:2442-55.

72. Heathcote EJ, Marcellin P, Buti M, et al. Three-year efficacy and safety of tenofovir disoproxil fumarate treatment for chronic hepatitis B. Gastroenterology. 2011;140:132-43.

73. - Snow-Lampart A, Chappell B, Curtis M, et al. No resistance to tenofovir disoproxil fumarate detected after up to 144 weeks of therapy in patients monoinfected with chronic hepatitis B virus. Hepatology. 2011;53:763-73. This article describes zero resistance with long term use of TDF in patients with chronic hepatitis $B$ monoinfection.

74. Heathcote EJ, Gane EJ, DdeMan RA, et al. Long term (4 year) efficacy and safety of tenofovir disoproxil fumarate (TDF) treatment in $\mathrm{HBeAg}$-positive patients $(\mathrm{HBeAg}+)$ with chronic hepatitis B (study 103): preliminary analysis (abstract). Hepatology. 2010;52(4(Suppl)):556A.

75. Marcellin P, Buti M, Krastev Z, Gurel S, et al. Continued efficacy and safety through 4 years of tenofovir disoproxil fumurate (TDF) treatment in HBeAg-negative patients with chronic hepatitis B (study 102): preliminary analysis (abstract). Hepatology. 2010;52 (4(Suppl)):555A.

76. Patterson SJ, George J, Strasser SI, et al. Tenofovir disoproxil fumarate rescue therapy following failure of both lamivudine and adefovir dipivoxil in chronic hepatitis B. Gut. 2011;60:247-54.
77. Qi X, Xiong S, Yang H, et al. In vitro susceptibility of adefovirassociated hepatitis B virus polymerase mutations to other antiviral agents. Antivir Ther. 2007;12:355-62.

78. Villet S, Pichoud C, Billioud G, et al. Impact of hepatitis B virus rtA181V/T mutants on hepatitis B treatment failure. J Hepatol. 2008;48:747-55.

79. van Bommel F, de Man RA, Wedemeyer H, et al. Long-term efficacy of tenofovir monotherapy for hepatitis B virusmonoinfected patients after failure of nucleoside/nucleotide analogues. Hepatology. 2010;51:73-80.

80. Berg T, Marcellin P, Zoulim F, et al. Tenofovir is effective alone or with emtricitabine in adefovir-treated patients with chronichepatitis B virus infection. Gastroenterology. 2010;139:1207-17.

81. Liaw YF, Sheen IS, Lee CM, et al. Tenofovir disoproxil fumarate (TDF), emtricitabine/TDF, and entecavir in patients with decompensated chronic hepatitis B liver disease. Hepatology. 2011;53:62-72.

82. Sheldon J, Camino N, Rodes B, et al. Selection of hepatitis B virus polymerase mutations in HIV-coinfected patients treated with tenofovir. Antivir Ther. 2005;10:727-34.

83. Delaney WEt, Ray AS, Yang H, et al. Intracellular metabolism and in vitro activity of tenofovir against hepatitis B virus. Antimicrob Agents Chemother. 2006;50:2471-7.

84. de Vries-Sluijs TE, Reijnders JG, Hansen BE, et al. Long-term therapy with tenofovir is effective for patients co-infected with human immunodeficiency virus and hepatitis B virus. Gastroenterology. 2010;139:1934-41.

85. Labarga P, Barreiro P, Martin-Carbonero L, et al. Kidney tubular abnormalities in the absence of impaired glomerular function in HIV patients treated with tenofovir. AIDS. 2009;23:689-96.

86. Karras A, Lafaurie M, Furco A, et al. Tenofovir-related nephrotoxicity in human immunodeficiency virus-infected patients: three cases of renal failure, Fanconi syndrome, and nephrogenic diabetes insipidus. Clin Infect Dis. 2003;36:1070-3. 